\title{
Strategic Alliances In The Food And Beverage Industry
}

Charles J. Cante, (E-mail: ccante@iona.edu), Iona College

Vincent J. Calluzzo, (E-mail: vcalluzzo@iona.edu), Iona College

Huldah A. Ryan, (E-mail: hryan@iona.edu), Iona College

\begin{abstract}
Strategic Alliances are an important component of an effective Total Quality Management program (TQM) and of business growth. The Food and Beverage industry was studied as part of a long-term longitudinal research program, covering diverse industries, to determine the extent of penetration and effectiveness of strategic alliances and TQM. The results indicated that $62 \%$ of respondents participate in strategic alliances and $82 \%$ practice TQM. Over $74 \%$ of firms that did participate reported achieving or exceeded alliance goals and, significantly, $73 \%$ experienced increased business revenue. Approximately $11.84 \%$ of participants reported that costs exceeded expectations while $15.13 \%$ enjoyed lower costs. Some methods to enhance strategic alliance effectiveness are discussed.
\end{abstract}

Total Quality Management (TQM) is a philosophy that includes the idea that to achieve the highest level of quality one must extend the quality system and program as far back in the Supply Chain as possible, i.e., to the supplier(s), the supplier's supplier and beyond if applicable (first, second, third, etc., tier suppliers), and as far forward as possible, i.e., to customers ${ }^{1}$. TQM also embraces the following five concepts namely; continuous improvement (a never ending search for perfection), bench-marking (learning from the "best-of-the best or "best-in-class"), use of empowered employee teams ${ }^{6}$, just-in-time practices (JIT) (use of strategic alliances and few suppliers ${ }^{2}$ ), and knowledge of tools (at least 51 tools including Statistical Quality Control ${ }^{3}$ ).

JIT practices include the use of strategic alliances; which may be with first, second and third tier suppliers and/or with customers; to achieve competitive advantages as well as to improve quality throughout the business system of an enterprise. ${ }^{2}$ A Strategic Alliance is a formal agreement to supply a $\operatorname{good}(s)$ or services( $s)$ and to jointly expand knowledge, develop applications and commercialize new products, with the rights of co-ownership, and commercial exploitation of the inventions within the boundaries of the Alliance particulars. Alliance partners work together to serve the ultimate consumer by doing together what each partner could not do alone. The Strategic Alliance agreement includes Supply, Technology, Intellectual Property, Legal and Termination/Disengagement sub-agreements and, generally, has a term of at least 3 years but not usually more than 5 years. The objective of a Strategic Alliance is to achieve competitive advantage for each partner through productivity and quality improvements and significant innovation. ${ }^{2}$

This research was undertaken to determine the penetration of TQM and strategic alliances in the Food and Beverage industry. The intent is to re-study this industry in about 4 to 5 years to understand the evolution of TQM and strategic alliances from the baseline reported herein. The authors comprise the Strategic Alliance Research Group that expects to study a broad array of US industries on these subjects. ${ }^{5}$ The reader is referred to the authors' Web site at www.tsarg.com for the organization's vision, mission, objectives and recent research.

Readers with comments or questions are encouraged to contact the authors via email. 


\subsection{The Approach To The Research}

An 18-question survey was the instrument employed to obtain the information about the food and beverage industry. The survey is shown in appendix 1. This industry is comprised of approximately 2000 food processors, food distributors, suppliers of raw material, ingredients, packaging materials and process equipment, and food retailers. 500 firms were randomly selected from those represented by individuals listed in the 2000 Membership Directory of the Institute of Food Technologists. ${ }^{4}$ This sample represents approximately $25 \%$ of such firms. 50 firms responded which represents $10 \%$ of the sample and, approximately, $2.5 \%$ of the total population of Food and Beverage firms. Twenty-six of the respondents (52\%) had revenues of $\$ 100$ million or less while $8(16 \%)$ had $\$ 1$ billion or more (table 1).

\subsection{The Discovery}

Given that the use of Strategic Alliances is an important facet of the practice of TQM, the first analysis sought the extent of participation by the respondents in both. The results showed that 31 respondents (62\%) engaged in Strategic Alliances (table 2). The research also showed that 36\% broadly practiced TQM while another $46 \%$ partially practiced TQM i.e., one or more of the five concepts were practiced (table 3). Hence about $82 \%$ of respondents practice TQM. A large proportion of TQM practitioners, 58.5\% (24 of 41), also engage in strategic alliances and $77.4 \%$ (24 of 31 ) of participants in strategic alliances practice TQM (table 4).

It was hypothesized that whether a company has sufficient resources to participate in either TQM or Strategic Alliances or both is a function of the size of an enterprise as measured in \$Revenue. This hypothesis was generally supported for strategic alliance participation as can be seen in table 5. However, the practice of TQM was essentially the same for all groups (table 6). From table 5, one can see that $50 \%$ of small companies (under $\$ 100$ million in revenue) participated in alliances as compared to $62.5 \%$ for medium size companies (\$101-999 million) and $100 \%$ for large companies (greater than $\$ 1$ billion). On the other hand, from table 6 , one can see that $80.77 \%$ of small companies practiced TQM as did $81.25 \%$ of medium size companies and $87.5 \%$ of large companies.

With an understanding of the penetration of TQM and Strategic Alliances in the Food and Beverage industry, the next question is "in how many alliances do firms participate?" From table 7, one can see that participating companies generally have two or three strategic alliances ( $16.1 \%$ and $32.3 \%$ respectively). Astonishingly, seven companies out of $31(22.6 \%)$ reported participating in "10 or more" alliances (table 7 ).

Does the number of alliances relate to a company's revenue? As noted in table 5, the answer is "no" as smaller enterprises tend to have more alliances. This may be an indicator that those smaller firms that recognize the need to participate in strategic alliances also recognize the need to more broadly augment their core competencies.

Let's examine the nature of the strategic alliances by moving backwards and forward into the Supply Chain. Before doing so, to facilitate the understanding of the discussion that follows; and of tables $8,11,12$, and 13; it is important to note that a company may enter into more than one separate alliance with a given partner. Also an alliance may have more than two partners. The respondents in this study reported a total of 163 alliances, eight of which appeared to be too new to discuss (net $=155$ alliances). The next question is "how many alliances are with direct suppliers (first tier) and with suppliers' suppliers (second tier) and with direct customers?" Moving backwards in the Supply Chain, 23 participating companies (74.2\%) have alliances with direct suppliers while only 5 companies have a second tier alliance $(16.2 \%)$. The former has a total of 96 alliances while the latter has eleven. On the other hand, moving forward in the Supply Chain, there are 14 companies that have alliances with customers $(45.2 \%)$. These companies have a total of 29 or more alliances with customers.

Another point to consider is the types of services that are covered by Strategic Alliances in the Food and Beverage industry that are not with suppliers or customers and the number of partners included in each of these alliances. This is presented in table 8 that shows that $30 \%$ of alliances are with packaging technology firms, $26.67 \%$ with manufacturing firms and $43.33 \%$ are spread over a broad array of services. 
The degree of success and satisfaction with current Strategic Alliances will determine the future deployment. Success and satisfaction can be measured in terms of results and cost as compared to expectations. The respondents were asked to evaluate the performance of their alliances in terms of achievement vs. expectations and cost vs. original forecast. From table 9, one can see that a majority of alliances "met or exceeded" expectations (74.84\%). Only $13.55 \%$ "did not meet" expectations at all. This outcome is an outstanding positive in favor of Strategic Alliances. On the other hand, as shown in table 10, the cost of Strategic Alliance participation was on "on plan" in $73.03 \%$ of the alliances and substantially more than original forecasts in only $11.84 \%$ (5.92\% reporting "higher" costs of 3-10\% and $5.92 \%$ reporting "significantly higher" costs of $11 \%$ or greater). On a positive note, $15.13 \%$ of Alliances experienced "lower or significantly lower" costs (table 10).

Given the excellent results for performance and cost, it is interesting to discover how many alliances will continue with current partners or with new partners and how many will be discontinued. From tables 11,12 and 13 respectively, one can see that 28 respondents will continue 128 alliances with current partners, 7 will continue 24 alliances but with new partners and 6 respondents will discontinue 11 alliances completely ( $\mathrm{N}=163$ alliances). Another key element of TQM and JIT is to have fewer suppliers. The respondents were asked if participation in strategic alliances resulted in having fewer suppliers. The majority of participants, $58.62 \%$, indicated a reduction in the number of suppliers (table 14).

Another important test of success and satisfaction with Strategic Alliances is whether or not a company's business increased as a result of participation. Hendricks and Singhal have shown that positive financial performance is linked to successful implementation of TQM. ${ }^{7}$ As one can see from table 15, a significant majority (73.08\%) of alliance participants enjoyed increased business- a superior outcome.

The respondents who participated in Strategic Alliances were asked to indicate their Top-5 Advantages and Top-5 Disadvantages of participation. The results are shown in tables 16 and 17. The advantages give some insight into why business increased for $73.08 \% \%$ of that population. On the other hand, all of the disadvantages can be accounted for in terms of obstacles to effective TQM initiatives in 4 of the 7 criteria for the Malcolm Baldridge National Quality Award (MBNQA) namely, Leadership, Strategic Planning, Customer and Market focus and Business Results as discussed by Tamimi and Sebastianelli. ${ }^{8}$ These disadvantages can be overcome, and hence, show the opportunity for the future. The carrot is superior stock market performance as noted by Tai and Przasnyski. ${ }^{9}$ These authors analyzed the performance of a non-existent quality fund comprised of the stocks of all of the winners of the MBNQA, through 1996, adjusted for risk and market movement, in comparison to the performance of the Standard and Poor's (S\&P) 500 Index. They found that the "fund" outperformed stocks with similar risks. ${ }^{9}$

\subsection{The Outlook For The Future}

The successful utilization of Strategic Alliances and TQM in the Food and Beverage industry can readily be enhanced as discussed in the following. First, early meaningful accomplishments are important for cross-partner team morale, unity and effectiveness. ${ }^{2,5,6}$ To ensure that this happens, it is critical that participants develop clear, well defined, attainable and measurable objectives complete with milestones and timetables. Second, it is also important to develop "stretch" objectives that either "push the edge of the envelope" or are "out-of-the-box" opportunities. The accomplishment of attainable objectives fuels the attainment of the more difficult stretch objectives. Third, participants need to develop realistic cost expectations for both levels of objectives. Too often costs (human, budgetary, capital and others) are underestimated either to make participation appear more appealing or because there is insufficient time in the approval process to understand and quantify all elements of cost. Fourth, participants need to develop, organize and staff joint teams to execute that which is necessary to accomplish the Alliance objectives. ${ }^{2}$ These teams need to be empowered in order to capitalize on and exploit successes. ${ }^{6}$ Fifth, it is essential that companies undertake only the "critical few" alliances and drive these to success as opposed to entering many alliances and diffusing their energy. By focusing on the "critical few" the probability of success is likely to improve as will the ability to manage and control costs. Finally, one must keep in mind that alliances are formed to achieve desired results and not to have lives of their own hence, these should be redefined with new objectives or terminated and new ones initiated, as appropriate. 
Many respondents did not participate in strategic alliances (42\%) or TQM (18\%) because they believed that they had insufficient resources and would be diluting their current business effort and, or, they lacked the belief in or understanding of the principles and concepts of TQM. The authors recommend that these companies seek assistance from those individuals or organizations experienced in TQM and the construction and execution of Strategic Alliances then undertake a single alliance with which to gain increased business while gaining experience and confidence.

\subsection{Postscript}

The Food and Beverage industry has much to gain by participating in those Strategic Alliances that bring added value to their customers and consumers. Consider, for example, Elizabeth Sloan's "Top 10 Trends to Watch and Work On" for the food and beverage industry that include "Do-it-for-me" foods, "Super Savory and Sophisticated", "Balance", "Form Follows Function", "A New Kind of Home-Spun", "Kid-Influenced", "Light and Lively", "Crossover Meal Patterns", "Do-it-yourself Health" and "Clean, Pure Natural and Safe". ${ }^{10}$ These trends, which have been taking shape over the last 10 years, will require a broad array of competencies (disciplines, skills and technologies) in order to satisfy the consumer's needs. While it is obvious that product, package and process technologies are essential so are others such as supply-chain management, computer-controlled warehousing and distribution, and sales (perhaps Efficient Consumer Response). No one industry member, regardless of size, can afford the human, physical and monetary resources to go it alone. This reality has been taking root over the last 10 years as well. In a 1996 survey of food manufacturers, Hoban reported that suppliers and customers were an important source of new product ideas and technologies (24\% and 53\% respectively) as well as positive elements for new product success (33\% and $47 \%$ respectively). ${ }^{11}$ Outsourcing of non-core competencies or business activities provides an avenue to augment a firm's effort. ${ }^{12}$. However, the use of strategic alliances is a superior way to achieve a competitive advantage at an affordable cost. ${ }^{6}$ As Dodge and Salahuddin stated, "Put simply, a strategic alliance is a relationship between firms to create more value than they can on their own." ${ }^{13}$ At IFT Food Expo 2001, Dahm reported that several speakers cited "increasing demand and dependence upon suppliers and external partnerships" and that has resulted in "a consolidation of the supplier base with an expansion of suppliers' roles." 14 Clearly, mergers and acquisitions in the industry have exacerbated the situation by reducing the internal resources of the newly formed enterprise. $^{15,16}$

Let's examine a few strategic alliances that have been publicly announced and illustrate what is possible. These cover warehousing and distribution technology, global material sourcing, supply-chain efficiency and selling. In an effort to increase service level and fill rates at its Acme stores, F.W. Albrecht Grocery Company (Albrecht) entered into a warehousing and distribution alliance with the Fleming Companies that employs advanced technology in its warehouses. ${ }^{17}$ This alliance allows Albrecht to focus on its core retailing strength while Fleming focuses on its core strength in effective inventory management. In another example, General Nutrition Companies (GNC) formed an alliance with Mitsubishi International Corporation to produce selected nutrition supplements in the United States and Canada. ${ }^{18}$ This alliance allows GNC to benefit from Mitsubishi's global raw material sourcing in exchange for participation in the retail revenues of the resulting products. Also consider the alliance formed between Compass, a global catering enterprise, and Kraft Jacob Suchard, the European component of Kraft Foods, Inc., in which Kraft will supply Compass with all of its coffee requirements in Europe. ${ }^{20}$ Compass gains the advantage of Kraft's scale in global coffee sourcing (lower cost, higher quality beans) and processing (higher quality, greater consistency of the finished coffee) while Kraft improves its asset utilization. In another alliance aimed at improving the accuracy of demand forecasts and store re-supply, Safeway, a supermarket chain, and Dreyer's, an ice cream producer, implemented a scan-based pilot in which Dreyer's payments are based on real product movement at Safeway's checkout scanners. ${ }^{19}$ This shift away from paying Dreyer's for product delivery to paying for actual sales forces the development of improved forecasting and, hence, should positively impact the vendor's entire supply-chain. The technology is in place at supermarkets through the checkout scanners, which read the Universal Product Codes (UPC) so the only other requisite is an agreement to share the consumer-take information (one of the aims of the alliance) in exchange for better business performance for both partners. Lastly, in an alliance between Starbucks Corporation and Kraft Foods, Inc., the latter will use its marketing, sales and distribution power to bring the former's premium quality coffee beans to retail in US groceries. ${ }^{21}$ These examples barely scratch the surface of what is possible. 


\subsection{Endnotes}

1. Heizer, Jay and Barry Render. 2001. Operations Management. Upper Saddle River, NJ: Prentice-Hall, 174.

2. Cante, Charles J. 1998. "Strategic Supplier Alliances: Pathways for Success." Proceedings of the $80^{\text {th }}$ Annual Convention of the National Association of Fruits, Flavors and Syrups. Long Boat Key, FL: National Association for Fruits, Flavors and Syrups, 6-7, 32.

3. $\quad$ Tague, Nancy R.1995. The Quality Toolbox. Milwaukee, WI: ASQC Quality Press.

4. $\quad$ The IFT Membership Directory 2000. Chicago, IL: The Institute of Food Technologists, 21-366.

5. Cante, Charles J. and Vincent J. Calluzzo. "The State of Strategic Alliances in the Executive Recruiting Industry." Submitted March 2002 to Executive. The Academy of Management.

6. $\quad$ Cante, Charles J. 1999. "Food Product Development Strategies.” Przemysl Spozywcsy. Vol 53, 12-15.

7. Hendricks, Kevin B. and Vinod R. Singhal. April 1999. "Don't Count TQM Out." Quality Progress, 35-42.

8. Tamimi, Nabil and Rose Sebastianelli. June 1998. "The Barriers to Total Quality Management." Quality Progress, 57-60.

9. Tai, Lawrence and Zbigniew H. Przasnyski. April 1999. Baldridge Award Winners Beat the S\&P500. Quality Progress, 45-51.

10. A. Elizabeth Sloan. April 2001. "Top 10 Trends to Watch and Work On." $3^{\text {rd }}$ Biannual Report. Food Technology. Vol. 55, 38-58.

11. Hoban, Thomas J. Jan.1998. "Improving the Success of New Product Development." Food Technology. Vol. 52, 46-49.

12. Patterson, Jennifer and Stephen Haas. October 1999. "A rationale for Outsourcing." Food Technology. Vol. 53, 52-56.

13. Dodge, David D. and Mabashir A. Salahuddin. Jan.-Mar. 1998. Business \& Economic Review, 18-20.

14. Dahm, Lori. July 2001. IFT Food Expo 2001. Stagnito's New Products Magazine, Stagnito Communications Inc., 37-43.

15. Mermelstein, Neil H., Editor. September 2001. "Developing Foods. A Food Technology Special Report. Top Executives Analyze Food R\&D in 2001 and Beyond." Food Technology. Vol. 55, 36-58.

16. Rosskam, Skip. July 2001. "New R\&D Strategies in the Flavor Industry." Food Technology. Vol. 55, 5257.

17. Purpura, Linda. February 2, 1998. "Flemings Cos. To Supply 30 Acme Units for Albrecht." Supermarket News, 47. 〈http://web.lexis-nexis.com/univers>

18. News In A Minute. January 5, 1998. The Food Institute Report. American Institute of Food Distribution Inc. 〈http://web.lexis-nexis.com/univers>

19. Amato-McCoy, Deena. March 16, 1998. “Safeway Plans Scan-Based Trade Rollout By Year-End.” Supermarket News, 43. <http://web.lexis-nexis.com/univers>

20. Larsen, Peter Thal. October 7, 1998. "Coffee supply deal cuts Compass costs." The Independent (London), 23. <http://web.lexis-nexis.com/univers>

21. Associated Press. September 28, 1998 (Seattle). "Kraft to Put Starbucks Bean in Groceries." The New York Times, September 29, 1998, Late Edition, C21. 〈http://web.lexis-nexis.com/univers〉 


\section{TABLES}

Table1. Revenue distribution of Respondents

\begin{tabular}{|c|c|c|}
\hline Revenue for 1998 & $\#$ & $\%$ \\
\hline $\mathrm{x}<100$ million & 26 & $52.00 \%$ \\
\hline 100 million $<=\mathrm{x}<250$ million & 5 & $10.00 \%$ \\
\hline 250 million $<=\mathrm{x}<500$ million & 6 & $12.00 \%$ \\
\hline 500 million $<=\mathrm{x}<750$ million & 3 & $6.00 \%$ \\
\hline 750 million $<=\mathrm{x}<1$ billion & 2 & $4.00 \%$ \\
\hline 1 billion $<=\mathrm{x}<2.5$ billion & 3 & $6.00 \%$ \\
\hline 2.5 billion $<=\mathrm{x}<5$ billion & 3 & $6.00 \%$ \\
\hline 5 billion $<=\mathrm{x}<10$ billion & 1 & $2.00 \%$ \\
\hline$>10$ billion & 1 & $2.00 \%$ \\
\hline Totals & 50 & $100.00 \%$ \\
\hline
\end{tabular}

Table 2.How many engage in Strategic Alliances?

\begin{tabular}{|c|c|c|}
\hline Yes & 31 & $62 \%$ \\
\hline No & 19 & $38 \%$ \\
\hline Totals & 50 & $100 \%$ \\
\hline
\end{tabular}

Table 3. Practice TQM?

\begin{tabular}{|c|c|c|}
\hline Yes & 18 & $36.00 \%$ \\
\hline No & 9 & $18.00 \%$ \\
\hline Partially & 23 & $46.00 \%$ \\
\hline Totals & 50 & $100.00 \%$ \\
\hline
\end{tabular}

Table 4. \# of Strategic Alliances and Practice TQM

\begin{tabular}{|c|c|c|c|c|}
\hline Strategic Alliances & yes & no & partially & total \\
\hline 0 & 8 & 2 & 9 & 19 \\
\hline 1 & 2 & & & 2 \\
\hline 2 & & 2 & 3 & 5 \\
\hline 3 & 2 & 2 & 6 & 10 \\
\hline 4 & 1 & 1 & 1 & 3 \\
\hline 5 & & & 1 & 1 \\
\hline 6 & 1 & & & 1 \\
\hline 7 & 1 & & 1 & 2 \\
\hline 10 & 3 & 2 & 2 & 7 \\
\hline Totals & 18 & 9 & 23 & 50 \\
\hline
\end{tabular}


Table 5. Does \# of alliances relate to company revenue?

\begin{tabular}{|c|c|c|c|c|c|c|c|c|c|c|c|c|}
\hline Revenue for 1998 & $\mathbf{0}$ & 1 & 2 & 3 & 4 & 5 & 6 & 7 & 8 & 9 & 10+ & total \\
\hline $\mathrm{x}<100$ million & 13 & 1 & 2 & 5 & 2 & & & & & & 3 & 26 \\
\hline 100 million $<=\mathrm{x}<250$ million & 3 & & & & & & & 1 & & & 1 & 5 \\
\hline 250 million $<=\mathrm{x}<500$ million & 1 & 1 & 2 & 2 & & & & & & & & 6 \\
\hline 500 million $<=\mathrm{x}<750$ million & 1 & & 1 & 1 & & & & & & & & 3 \\
\hline 750 million $<=\mathrm{x}<1$ billion & 1 & & & & & & & & & & 1 & 2 \\
\hline 1 billion $<=\mathrm{x}<2.5$ billion & & & & 1 & 1 & & & 1 & & & & 3 \\
\hline 2.5 billion $<=\mathrm{x}<5$ billion & & & & 1 & & 1 & & & & & 1 & 3 \\
\hline 5 billion $<=\mathrm{x}<10$ billion & & & & & & & & & & & 1 & 1 \\
\hline$>10$ billion & & & & & & & 1 & & & & & 1 \\
\hline Totals & 19 & 2 & 5 & 10 & 3 & 1 & 1 & 2 & 0 & 0 & 7 & 50 \\
\hline
\end{tabular}

Table 6. \$Revenue and Practice TQM

\begin{tabular}{|c|c|c|c|c|}
\hline Revenue for $\mathbf{1 9 9 8}$ & yes & no & partially & total \\
\hline $\mathrm{x}<100$ million & 9 & 5 & 12 & 26 \\
\hline 100 million $<=\mathrm{x}<250$ million & 2 & & 3 & 5 \\
\hline 250 million $<=\mathrm{x}<500$ million & 2 & 1 & 1 & 6 \\
\hline 500 million $<=\mathrm{x}<750$ million & 1 & 1 & 1 & 3 \\
\hline 750 million $<=\mathrm{x}<1$ billion & & 1 & 2 & 3 \\
\hline 1 billion $<=\mathrm{x}<2.5$ billion & 1 & & & 1 \\
\hline 2.5 billion $<=\mathrm{x}<5$ billion & 1 & & & 1 \\
\hline 5 billion $<=\mathrm{x}<10$ billion & 1 & & & 5 \\
\hline $\mathrm{x}>10$ billion & 1 & 9 & & 5 \\
\hline Totals & 18 & & & \\
\hline
\end{tabular}

Table 7. How many in $0,1,2$, etc, alliances?

\begin{tabular}{|c|c|c|c|}
\hline \#of alliances & \#of respondents & \% of total & \% of alliance participation \\
\hline 0 & 19 & $38.00 \%$ & not applicable \\
\hline 1 & 2 & $4.00 \%$ & $6.45 \%$ \\
\hline 2 & 5 & $10.00 \%$ & $16.14 \%$ \\
\hline 3 & 10 & $20.00 \%$ & $32.26 \%$ \\
\hline 4 & 3 & $6.00 \%$ & $9.68 \%$ \\
\hline 5 & 1 & $2.00 \%$ & $3.22 \%$ \\
\hline 6 & 1 & $2.00 \%$ & $3.22 \%$ \\
\hline 7 & 2 & $4.00 \%$ & $6.45 \%$ \\
\hline 8 & & $0.00 \%$ & $0 \%$ \\
\hline 9 & & $0.00 \%$ & $0 \%$ \\
\hline 10 or more & 7 & $14.00 \%$ & $22.58 \%$ \\
\hline Totals & 50 & $100.00 \%$ & $100.00 \%$ \\
\hline
\end{tabular}


Table 8. Number of partners vs. type of service

\begin{tabular}{|c|c|c|c|c|}
\hline Type of service & $\begin{array}{c}\text { Number } \\
\text { responded }\end{array}$ & $\begin{array}{c}\text { \% of those } \\
\text { that responded }\end{array}$ & $\begin{array}{c}\text { Number of } \\
\text { alliances }\end{array}$ & $\begin{array}{c}\text { of the number } \\
\text { of alliances }\end{array}$ \\
\hline Product technology & 1 & $5.56 \%$ & 2 & $6.67 \%$ \\
\hline Process technology & 1 & $5.56 \%$ & 1 & $3.33 \%$ \\
\hline Packaging technology & 4 & $22.22 \%$ & 1 & $30.00 \%$ \\
\hline Basic technical research & 1 & $5.56 \%$ & 1 & $3.33 \%$ \\
\hline Information technology & 1 & $5.56 \%$ & 0 & $3.33 \%$ \\
\hline Distribution technology & 0 & $0.00 \%$ & 0 & $0.00 \%$ \\
\hline Sales & 0 & $0.00 \%$ & 1 & $0.00 \%$ \\
\hline Marketing & 1 & $5.56 \%$ & 1 & $3.33 \%$ \\
\hline Market research & 1 & $5.56 \%$ & 3 & $3.33 \%$ \\
\hline Purchasing & 2 & $11.11 \%$ & 0 & $10.00 \%$ \\
\hline Supply chain management & 0 & $0.00 \%$ & 0 & $0.00 \%$ \\
\hline Quality & 0 & $0.00 \%$ & 8 & $0.00 \%$ \\
\hline Manufacturing & 4 & $22.22 \%$ & 0 & $26.67 \%$ \\
\hline Human resources & 0 & $0.00 \%$ & 3 & $0.00 \%$ \\
\hline Other $*$ & 2 & $11.11 \%$ & 30 & $10.00 \%$ \\
\hline Totals & 18 & $100.00 \%$ & & $100.00 \%$ \\
\hline
\end{tabular}

Table 9. Performance vs. Expectation

\begin{tabular}{|c|c|c|}
\hline Rating & $\mathbf{N}$ & $\boldsymbol{\%}$ \\
\hline Exceeded expectations & 47 & $30.32 \%$ \\
\hline Met expectations & 69 & $44.52 \%$ \\
\hline Marginally acceptable & 18 & $11.61 \%$ \\
\hline Did not meet expectations & 21 & $13.55 \%$ \\
\hline Total & 155 & $100.00 \%$ \\
\hline
\end{tabular}

Table 10. Cost vs. Expectation

\begin{tabular}{|c|c|c|}
\hline Rating & N & \% \\
\hline Significantly higher (11\%+) & 9 & $5.92 \%$ \\
\hline Higher (3-10\%) & 9 & $5.92 \%$ \\
\hline On Expectation (+/- 2\%) & 111 & $73.03 \%$ \\
\hline Lower (-3 to -10\%) & 20 & $13.16 \%$ \\
\hline Significantly lower (-11\% or less) & 3 & $1.97 \%$ \\
\hline Total & 152 & $100.00 \%$ \\
\hline
\end{tabular}


Table 11. How many SA will you continue with current partner?

\begin{tabular}{|c|c|c|}
\hline \# Alliances & \# Responses & \% of responses \\
\hline 1 & 3 & $10.71 \%$ \\
\hline 2 & 9 & $32.16 \%$ \\
\hline 3 & 5 & $17.86 \%$ \\
\hline 4 & 2 & $7.14 \%$ \\
\hline 6 & 2 & $7.14 \%$ \\
\hline 7 & 1 & $3.57 \%$ \\
\hline 8 & 1 & $3.57 \%$ \\
\hline 9 & 2 & $7.14 \%$ \\
\hline 10 & 1 & $3.57 \%$ \\
\hline 14 & 1 & $3.57 \%$ \\
\hline 15 & 1 & $3.57 \%$ \\
\hline Totals $(\mathrm{N}=128)$ & 28 & $100.00 \%$ \\
\hline
\end{tabular}

Table 12. How many SA will you continue with a different partner?

\begin{tabular}{|c|c|c|}
\hline \# Alliances & \# Responses & \% of responses \\
\hline 1 & 4 & $57 \%$ \\
\hline 2 & 2 & $28.6 \%$ \\
\hline 16 & 1 & $14.4 \%$ \\
\hline Totals $(\mathrm{N}=24)$ & 7 & $100.00 \%$ \\
\hline
\end{tabular}

Table 13. How many SA will you discontinue?

\begin{tabular}{|c|c|c|}
\hline \# Alliances & \# Responses & \% of responses \\
\hline 1 & 2 & $33.3 \%$ \\
\hline 2 & 3 & $50 \%$ \\
\hline 3 & 1 & $16.7 \%$ \\
\hline Totals $(\mathrm{N}=11)$ & 6 & $100.00 \%$ \\
\hline
\end{tabular}

Table 14.Did SA facilitate a reduction in \# of suppliers?

\begin{tabular}{|c|c|c|}
\hline Yes & 17 & $58.62 \%$ \\
\hline No & 12 & $41.38 \%$ \\
\hline Totals & 29 & $100.00 \%$ \\
\hline
\end{tabular}

Table 15. Did your business increase?

\begin{tabular}{|c|c|c|}
\hline Yes & 19 & $73.08 \%$ \\
\hline No & 7 & $26.92 \%$ \\
\hline Totals & 26 & $100.00 \%$ \\
\hline
\end{tabular}


Table 16. Top 5 advantages of alliance participation

\begin{tabular}{|c|}
\hline Cost Savings \\
\hline Improved Quality/Consistency \\
\hline Improved Service \\
\hline Increase Revenue \\
\hline Increased Profitability \\
\hline
\end{tabular}

Table 17. Top 5 disadvantages of alliance participation

\begin{tabular}{|c|}
\hline Communications \\
\hline Lack of Control \\
\hline Timing Issues \\
\hline Lack of Sincerity \\
\hline Pricing/Profit Issues \\
\hline
\end{tabular}

\section{Appendix 1}

\section{The State of Strategic Alliances in the Food \& Beverage Industry: SURVEY}

Your Company's confidential code is:

What is your job title and functional area:

1. What was your Food and Beverage \$Revenue for CY1998? ( circle one )
a. Less than $\$ 100$ million
b. Greater than $\$ 100$ million but less than $\$ 250$ million
c. Greater than $\$ 250$ million but less than $\$ 500$ million
d. Greater than $\$ 500$ million but less than $\$ 750$ million
e. Greater than $\$ 750$ million but less than $\$ 1$ billion
f. Greater than $\$ 1$ billion but less than $\$ 2.5$ billion
g. Greater than $\$ 2.5$ billion but less than $\$ 5$ billion
h. Greater than $\$ 5$ billion but less than $\$ 10$ billion
i. Greater than $\$ 10$ billion

2. What is your position in the Industry? (circle one)
a. Food Processor
b. Food Distributor
c. Ingredient Supplier
d. Raw Material Supplier
e. Packaging Material Supplier
f. Equipment Supplier
g. Service Provider
h. Food Retailer
i. Food Service
j. Other (please specify 
3. In how many Strategic Alliances does your Company participate? (circle one)

$0, \quad 1, \quad 2,3, \quad 4,5,6,7, \quad 8, \quad 9,10$ or more

IF YOUR ANSWER TO QUESTION (3) WAS “0” PLEASE PROCEED DIRECTLY TO OUESTION (18).

4. Please indicate the relative size of your Strategic Alliances Partners in \$Revenue..

$\begin{array}{ll}\text { \$Revenue } & \text { Number of Partners } \\ \$ 1-\$ 99 \text { million } & - \\ \$ 100-\$ 249 \text { million } & - \\ \$ 250-\$ 499 \text { million } & - \\ \$ 500-\$ 749 \text { million } & - \\ \$ 750-\$ 999 \text { million } & - \\ \$ 1-\$ 2.5 \text { billion } & \\ \$ 2.5-\$ 4.99 \text { billion } & \\ \$ 5-\$ 9.99 \text { billion } & \\ \$ 10 \text { billion and higher } & \end{array}$

5. How many of your Strategic Alliances are with your Suppliers? (circle one)

$0,1,2,3,4,5,6,7,8,9,10$ or more

6. How many of your Strategic Alliances are with your Suppliers' Suppliers? (circle one)

$0,1,2,3,4,5,6,7,8,9,10$ or more

7. How many of your Strategic Alliances are with your Customers? (circle one )

$0,1,2,3,4,5,6,7,8,9,10$ or more

8. How many of your Strategic Alliances are with Partners who are neither Suppliers nor Customers but are providers of services?

Type of Service

Product Technology

Process Technology

Packaging Technology

Basic Technical Research

Information Technology

Distribution Technology

Sales

Marketing

Market Research

Purchasing

Supply Chain Management

Quality

Manufacturing

Human Resources

Other (please specify) $\underline{\text { Number of Partners }}$

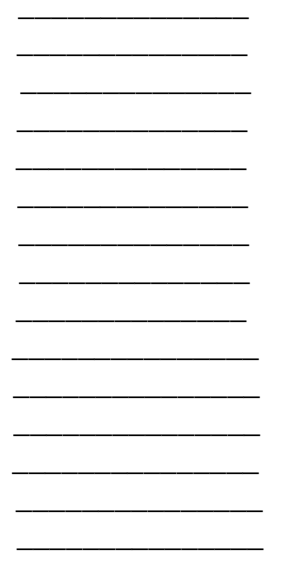


9. How do you rate the aggregate benefits of these Alliances compared to the expectations set forth in the Alliance agreements?

Rating Number of Alliances

Exceeded Expectations

Met Expectations

Marginally Acceptable

Did Not Meet Expectations

10. How do you rate the cost (\$, human, etc.) committed to the Alliances compared to your forecast at the onset of the Alliances.

$\underline{\text { Rating }}$

Significantly higher $(11 \%+)$

Higher (3-10\%)

On Expectation $(+/-2 \%)$

Lower $(-3$ to $-10 \%)$

Significantly lower (-11\% or less)

\section{Number of Alliances}

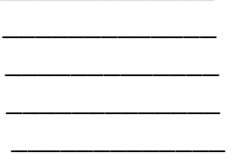

11. How many of your current Strategic Alliances do you expect to continue into another term with the current partners? Please enter the number:

12. How many of your current Strategic Alliances will you continue into a new term but with a different partner i.e., not the current partner? Please enter the number:

13. How many of your current Strategic Alliances will you discontinue at their conclusion because the objectives/purposes have been accomplished:

14. Did participation in Strategic Alliances facilitate a reduction in the number of your suppliers? (circle one)

YES NO

15. Did your business (revenue, income, volume or market share) increase as a result of participating in Strategic Alliances? ( circle one)

YES NO

16. Please list the 5 most important "satisfactions" your Company achieved through Strategic Alliances

17. Please list the 5 most important “dissatisfaction” noted from your Strategic Alliances.

18. Does your Company embrace and practice Total Quality Management (TQM) to include continuous improvement, benchmarking, just-in-time practices, employee empowerment, use of cross-functional teams and teaching/providing TQM tools to employees? (circle one)
NO
YES
PARTIALLY

19. Please feel free to note any comments you have on the subject of Strategic Alliances.

Please return the completed survey to : Dr. Charles J. Cante, Iona College, The Hagan School of Business, 715 North Avenue, New Rochelle, NY 10801-1890 